\title{
Corruption, Licensing and Elections - A New Analysis Framework
}

Drini Imami *

Abstract:

This paper analyses corruption and licensing in conjunction with elections in Albania. The paper develops an analysis framework utilizing datasets of two types of national licenses, namely licenses for media and notaries about which there have been concerns of transparency in Albania. In the months preceding elections, a higher number of both types of licenses are issued. One possible explanation for the "intensification of licensing" during pre-election months may be corruption, given that licensing is widely perceived as related to corruption in countries with high levels of corruption such as Albania.

Keywords: Corruption, Election

JEL: D72

DOI: $10.2478 / v 10033-012-0009-3$

\section{Introduction}

Previous research has identified many factors that are deemed to stand behind corruption. Factors that reduce corruption are democratization and trade liberalization (Tavares, 2005), fiscal decentralization (Fisman and Gatti, 2000), a greater degree of international integration (Sandholtz and Gray, 2003), openness to foreign trade and competition (Treisman, 2000; Ades and Di Tella, 1999), freedom of the press (Lederman et al, 2001), the efficiency and quality of judicial and legal systems (Herzfeld and Weiss, 2003). Among factors that positively affect corruption are low wages in public administrations (Van Rijckeghem and Weder, 1997) and low economic development (Treisman, 2000).

Corruption is often blamed for poverty, low investment and economic growth as well as poor services and infrastructure. It causes lower investments and economic growth (Mauro, 1995), and lowers the quality of (public) investments (Lambsdorff, 2007). Corruption also affects the allocation of human resources and entrepreneurial skills -companies need more "middlemen" to facilitate acquiring licenses rather than investing in improving productivity (Murphy et al, 1991).
While there is a rich literature about the possible causes and consequences of corruption, there has been limited research on the inter-relations between elections and corruption. Krause and Méndez (2009), based on empirical cross-country analysis, suggest that a perceived rise in corruption in public office is effectively punished by voters in the general elections, and that the increase in perceived corruption is punished more severely in countries with relatively brief exposure to democracy, which are typically more corrupt than more consolidated democracies. Peters and Welch (1980) found that corruption charges of candidates in U.S. House of Representatives contests result in the loss of votes. On the other hand, Fackler and Lin (1995) show that the higher the amount of information about corruption, the lower the electoral support for the party which has the presidency in the USA. In addition, Chang and Golden (2004), and Ferraz and Finan (2005), report similar

\section{* Drini Imami}

Agriculture University of Tirana

E-mail:drinimami@yahoo.com 
findings in Italy and Brazil, respectively.

Causality should be questioned - do voters punish the government for higher levels of perceived corruption in corrupt countries, or do governments increase "corruption/bribe income" before elections when they expect to lose elections (or vice-versa)? Should not a corrupt, "rational" government in a corrupt country seek to maximize its income before leaving power? And if the incumbent is aware that corruption is a/the determinant factor of success in elections, is it not more rational to always combat corruption before elections?

The focus of this paper is Albania, a country characterized by relatively high levels of corruption. During the time span of the analysis, parliamentary elections ${ }^{1}$ took place in June 2001, July 2005 and June 2009 (the previous parliamentary elections of 1996 and 1997 are not included in this analysis as they were not credible and heavily manipulated and especially in 1997, Albania was in complete socio-economic chaos) ${ }^{2}$. Election outcomes in 2005 and 2009 were foreseen to be very tight $^{3}{ }^{4}$, while there were no polls for 2001 to the best of the author's knowledge.

Only two general (parliamentary) elections were held since the Corruption Perception Index (CPI) of Transparency International was calculated for Albania (the CPI method is explained in the following section). The two election years 2005 and 2009 were characterized by a worsening of corruption in Albania (Table 1).

\begin{tabular}{ccc} 
Year & Rank & Score \\
\hline 2002 & 81 & 2.5 \\
2003 & 92 & 2.5 \\
2004 & 108 & 2.5 \\
2005 & 126 & 2.4 \\
2006 & 111 & 2.6 \\
2007 & 105 & 2.9 \\
2008 & 85 & 3.4 \\
2009 & 95 & 3.2 \\
2010 & 87 & 3.3 \\
\hline
\end{tabular}

Source: $\mathrm{TI}$

Table 1: $\mathrm{CPI}$ ranking and score of Albania ${ }^{5}$

\footnotetext{
${ }^{1}$ Albanian is a parliamentary republic, and therefore the parliamentary elections are by far the most important elections.

${ }^{2}$ http://www.freedomhouse.eu/nitransit/2005/albania2005.pdf, Last accessed in October 2011

${ }^{3}$ http://www.mjaft.org/pdf/final_report_wave\%202_EN.pdf, Last accessed in October 2011

${ }^{4}$ http://www.zogby.com/news/2009/06/29/zogby-internationalalbanian-election-exit-poll-projections/, Last accessed in October 2011

${ }^{5}$ The CPI should be interpreted as a ranking of countries with scores ranging from 0 (highly corrupt) to 10 (highly clean).
}

One could tend to associate worsening levels of corruption with elections. When the incumbent foresees losing elections, or when elections predictions are tight, increasing "bribe income" may become a priority government (ministers) may decide to raise as much money as possible for the following years of "unemployment" or in the opposition. In a corrupt country, with corrupt institutions (i.e. courts), money brings a certain level of "immunity", and facilitates political activity (in a corrupt country, there are segments of media, civil society etc. which are corrupted).

There are several weaknesses, however, in basing the analysis on CPI in Albania. First, the time series is too short to measure the statistical significance of such a change. Second, elections fall in the middle of the respective years, and therefore may not be judged based on CPI if the worsening of corruption took place in the quarters before, or after elections or was constant throughout the year.

Therefore, it is necessary to develop proxies of measuring corruption in more detailed dynamics, namely at the monthly level. In this paper, monthly proxies (or potential indicators) of corruption are analyzed in conjunction with elections.

\section{Research Questions and Hypotheses}

Before elections there is a strong incentive to intensify corrupt activities, especially if it is likely that a rotation may take place (already assuming legal impunity ${ }^{6}$ ). Even if the same political party/coalition is re-elected, often government composition is subject to change for various reasons, which implies that not all the same politicians will run the same institutions/ministries as a new government is formed. Therefore there are additional incentives for government constituents (ministers) to increase income from corruption before elections and also before leaving power.

The main hypothesis: Before elections corruption increases in order to increase income, on the one hand to prepare for possible loss (future unemployment), and/or to finance a number of activities and stakeholders in regard to elections campaign (be it media or even

\footnotetext{
${ }^{6}$ Note: In Albania so far there has not been a single politician found guilty on corruption charges despite being one of the most corrupt countries worldwide.

http://www.gazeta-

shqip.com/politike/53befedd4025b0736b06b5d48d006f9d.html, Last accessed in November 2011
} 


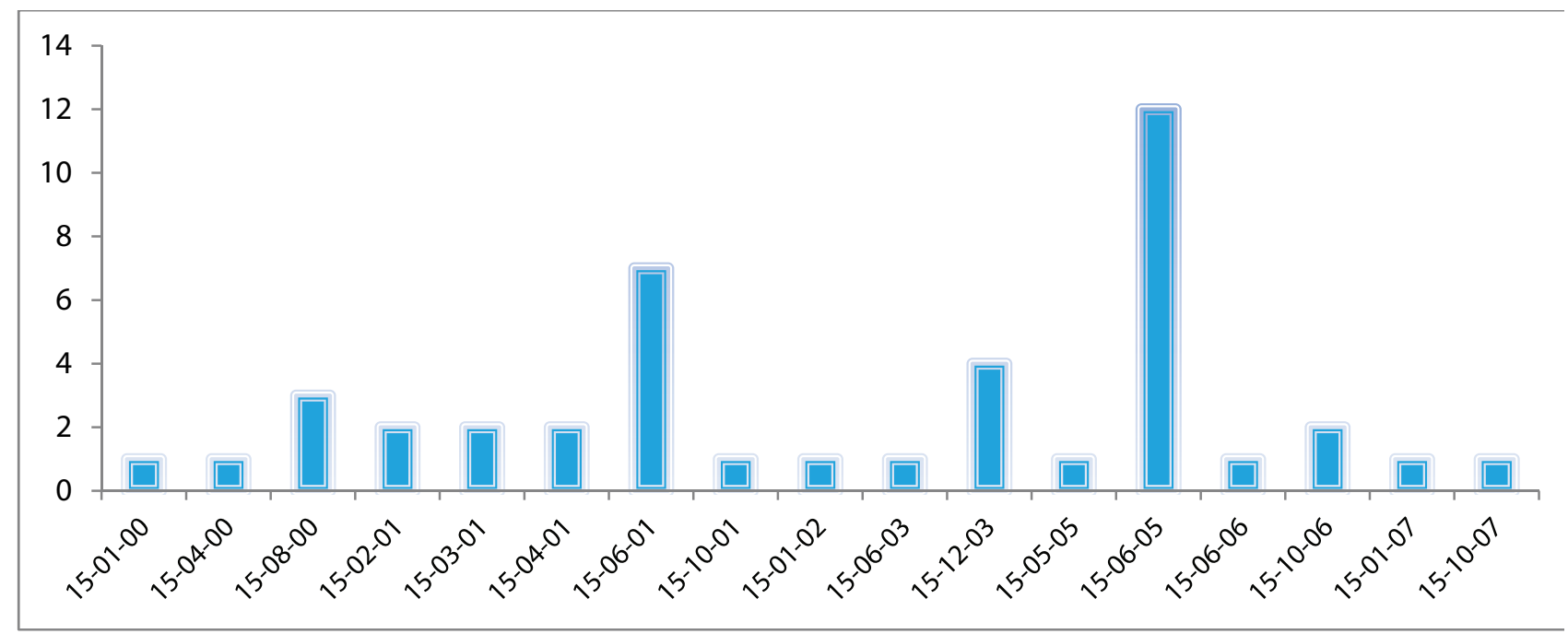

\begin{tabular}{lcccccccccccccccccc}
\hline Year & 2000 & 00 & 00 & 01 & 01 & 01 & 01 & 01 & 02 & 03 & 03 & 05 & 05 & 06 & 06 & 07 & 07 \\
\hline Month & 1 & 4 & 8 & 2 & 3 & 4 & 6 & 10 & 1 & 6 & 12 & 5 & 6 & 6 & 10 & 1 & 10 \\
Frequency & 1 & 1 & 3 & 2 & 2 & 2 & 7 & 1 & 1 & 1 & 4 & 1 & 12 & 1 & 2 & 1 & 1 \\
\hline
\end{tabular}

Source: QKL (National License Registration Center)

Figure 1: Granting of notary licenses during 2000- 2007

average voters ${ }^{7}$ ). Assuming that corruption affects various types of national licenses that have economic value, an alternative hypothesis would be: Before elections a higher number of licenses are issued. Both versions of the hypotheses hold particularly when the elections predictions/polls are tight or even more when the incumbent foresees to lose elections.

Data related to corruption are mostly generated through surveys which tend to measure perceived levels of corruption. One of the most common corruption indexes is the Transparency International Corruption Perceptions Index (CPI). CPI ranks countries in terms of the degree to which corruption is perceived to exist among public officials and politicians ${ }^{8}$. CPI is issued once a year, while there are no monthly proxy indicators used to assess corruption.

This paper analyzes the time series of licenses at the monthly level as a proxy (potential indicators) of corruption dynamics. Licensing activities are highly related to corruption. Government officials often collect bribes for providing permits and licenses (Shleifer and Vishny, 1993).

\footnotetext{
${ }^{7}$ In Albania it is reported that it is common that political activists pay voters in exchange for their votes.

http://www.revistamapo.com/lexo.php?id=2937, Last accessed in November, 2011.

${ }^{8}$ http://cpi.transparency.org/cpi2011/in_detail/, Accessed in May 2012
}

For that purpose, all of the time series of licences that were granted within a certain time span (a time series of several years) were checked that were available in public statistical databases (namely the QKL - Albanian National Licensing Centre for licenses and the Ministry of Finance for income from privatizations). The only datasets that have a relatively long time series are licenses for mining, TV and notaries. This paper analyzes all of these variables, except for mining licenses, which are subject to another research analysis.

There is no formal evidence of corruption for all the types of licences analyzed in Albania for the given period; however there are concerns about the transparency of the process of granting for both types of licences that are the object of this paper. The licensing process for private televisions and radios done by the National Council of Radio and Television in Albania has often been "labelled" as biased ${ }^{9}$. Regarding notary licensing, the OSCE (2004) has expressed concerns on the quality and transparency of testing.

This paper analyzes the time series of TV and notary licences relying on descriptive statistics, since the respective time series on one hand are not long and on the other hand, the descriptive analysis results are so

\footnotetext{
${ }^{9} \mathrm{http} / /$ www.institutemedia.org/newsletter2007.html, Last accessed in October 2011
} 


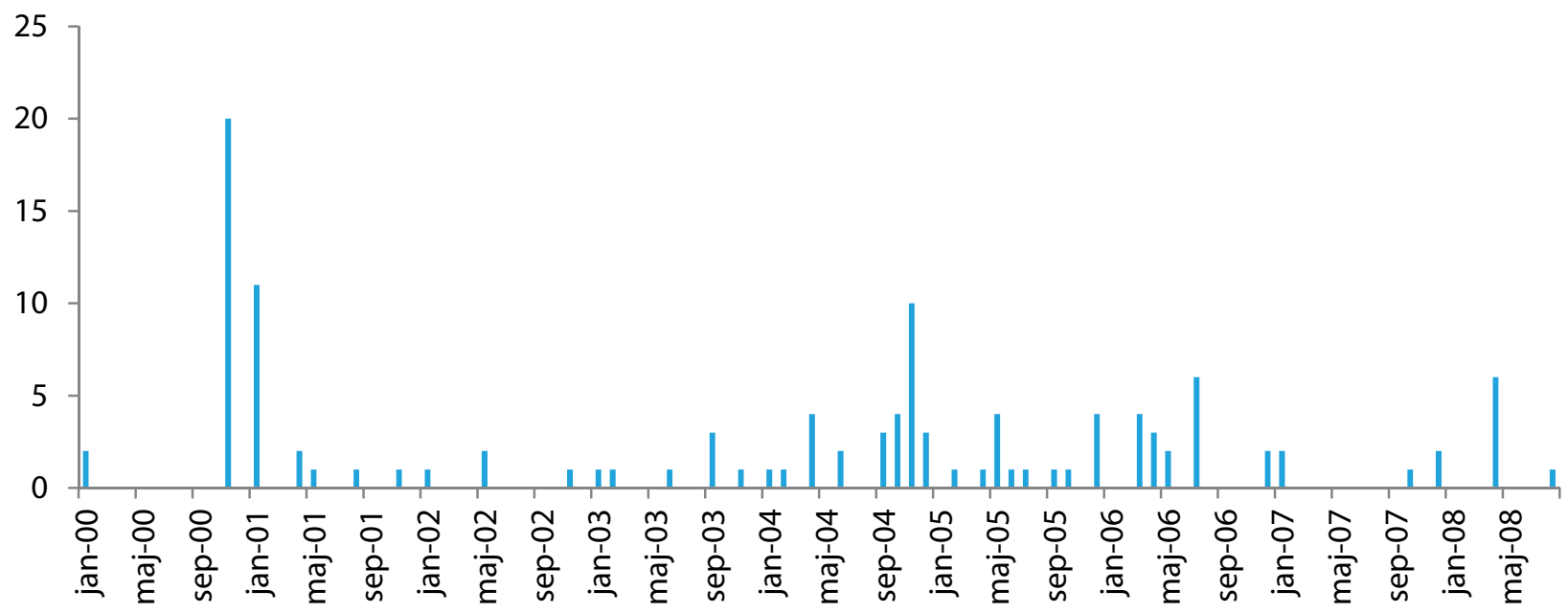

Source: QKL (National License Registration Center)

Figure 2: Granting of TV licenses during $2000-2008^{10}$

obvious that it is not necessary to apply complex econometrical analysis.

\section{Case Study: Licenses and Elections in Albania - $A$ Descriptive Analysis}

In the QKL (National Licensing Centre) licenses database, there were available data about notary licenses up to 2007. During $2000-2007$, there were recorded 43 notary licenses, and in that time-span fall the elections of 2001 (June) and 2005 (July). A total of 19 licenses were granted within a month from both election dates. Within the range of 6 months before elections, there were 25 licenses granted, or almost $60 \%$ of the total for the given period (Figure 1).

Regarding TV licenses, in the QKL database data were reported until July 2008. Within the last 12 months from the election date of both elections, 61 TV licenses were granted out of a total of 120 for the given period 2000 2008 , or more than half.

From the examples stated above, it is obvious that the licensing for such economically important activities intensifies drastically before elections, supporting the hypothesis of this paper - the closer to the elections, the more licenses are issued and the higher the corruption.

\section{Discussion of The Results and Conclusions}

Incumbents may engage more intensively in corruption, to increase "corruption income" before

\footnotetext{
${ }^{10}$ The dataset is available in appendix.
}

leaving power, especially when their re-election is not very likely. Alternatively, money may be needed to finance campaigns in a highly corrupted country, where corruption has affected most parts of the society, and therefore there is an incentive to expand corruption before elections.

This paper analyzed the issuing of licences for private TVs and notaries in conjunction with elections - there are clear indications that in the months or year before elections significantly more licenses are issued than during the other months or years. One explanation for the intensification of licensing may be corruption. These findings are in line with the findings of Imami et al. (2011) who analyzed monthly income from privatization in conjunction with the last three parliamentary elections in Albania, and found a statistically significant increase of income from privatization before elections, which leads to the conclusion that one of the reasons of "a more intensive privatization process" before elections may be corruption, as privatization is often linked to corruption in transition countries (Kaufmann and Siegelbaum, 1997).

Other reasons may be behind such behaviour related to licensing or privatization, but it is difficult or impossible to measure and control for "true" motivations. .

\section{References}

Ades, A. and Di Tella R. (1999) Rents, Competition and Corruption, American. Economic Review, Vol. 50, pp. 49-123.

Chang, E., and Golden M. A. (2004) Does Corruption Pay? The Survival of Politicians Charged with Malfeasance in the Postwar Italian Chamber. Paper presented at the annual Meeting of the American 
Political Science Association, Chicago, IL, Available at: http://www.golden.polisci.ucla.edu/recent_papers/wasedapaper.pdf

Fackler, T., and Lin T. M. (1995) Political Corruption and Presidential Elections, 1929-1992, Journal of Politics, 57(4), pp. 971-993.

Ferraz, C., and Finan F. (2008) Exposing Corrupt Politicians: The Effect of Brazil's Publicly Released Audits on Electoral Outcomes, The Quarterly Journal of Economics, 123(2), pp. 703 - 745,

Fisman, R. J. and Gatti, R. (2000) Decentralization and Corruption: Evidence across Countries, World Bank Policy Research Working Paper, No. 2290.

Herzfeld, T. and Weiss, C. R. (2003) Corruption and Legal (In)Effectiveness: An Empirical Investigation, European Journal of Political Economy, Vol. 19 (3), pp. 621-632.

Imami, D., Lami, E., Kaechelin, H. (2011) Political cycles in income from privatization - The case of Albania, BERG Working Paper Series, No. 77, University of Bamberg

Kaufmann, D. and Siegelbaum, P. (1997) Privatization and Corruption in Transition Economies, Journal of International Affairs Vol. 50 (2), pp. 419-464

Krause, S. and Méndez, F. (2009) Corruption and Elections: An Empirical Study for a Cross-Section of Countries, Journal of Economics \& Politics, Vol. 21 (2), pp. 179-200

Lambsdorff, J. G. (2007) The Institutional Economics of Corruption and Reform, Theory, Evidence and Policy, Cambridge University Press.

Lambsdorff, J. G. (2007) The Institutional Economics of Corruption and Reform, Theory, Evidence and Policy, Cambridge University Press.

Lederman, D., Loayza, N. and Soares, R. (2001) Accountability and Political Institutions Matter, World Bank Policy Research Working Paper, No. 2708.

Mauro, P. (1995) Corruption and Growth, The Quarterly Journal of Economics, MIT Press, vol. 110(3), pp. 681-712.

Murphy, K. , Shleifer, A. \& Vishny, R. W. (1991) The Allocation of Talent: Implications for Growth, The Quarterly Journal of Economics, MIT Press, vol. 106(2), pages 503-530

OSCE (2004) Legal Sector Report for Albania, Available at: www.osce.org/albania/23963, last accessed in October 2011

Peters, J. G., and Welch S. (1980) The Effects of Charges of Corruption on Voting Behavior in Congressional Elections, The American Political Science Review, 74(3), pp. 697-708.

QKL (National Licensing Center) Licences Database, Available at: http://www.qkl.gov.al/RegistriesInsideNLC.aspx, last accessed in October 2011

Sandholtz, W. and Gray, M. (2003) International integration and national corruption, International Organization, vol. 57, pp. 761-800.

Shleifer, A. and Vishny, R. W. (1993) Corruption, The Quarterly Journal of Economics, MIT Press, vol. 108(3), pp. 599-617.

Tavares, S. (2005) Does rapid liberalization increase corruption? Paper presented at the European Public Choice Society conference, University of Durham

Transparency International, www.transparency.org

Treisman, D. (2000) The causes of corruption: A cross-national study, Journal of Public Economics, vol. 76 (3), pp.399-457.

Van Rijckeghem, C. and Weder, B. (1997) Corruption and the Rate of Temptation: Do Low Wages in the Civil Service Cause Corruption? IMF Working Paper, 97/73.

\section{Appendix}

\begin{tabular}{cccc}
$\begin{array}{c}\text { Year and } \\
\text { Month }\end{array}$ & Frequency & $\begin{array}{c}\text { Year and } \\
\text { Month }\end{array}$ & Frequency \\
\hline Jan-00 & 2 & Nov-04 & 10 \\
Nov-00 & 20 & Dec-04 & 3 \\
Jan-01 & 11 & Feb-05 & 1 \\
Apr-01 & 2 & Apr-05 & 1 \\
May-01 & 1 & May-05 & 4 \\
Aug-01 & 1 & Jun-05 & 1 \\
Nov-01 & 1 & Jul-05 & 1 \\
Jan-02 & 1 & Sep-05 & 1 \\
May-02 & 2 & Oct-05 & 1 \\
Nov-02 & 1 & Dec-05 & 4 \\
Jan-03 & 1 & Mar-06 & 4 \\
Feb-03 & 1 & Apr-06 & 3 \\
Jun-03 & 1 & May-06 & 2 \\
Sep-03 & 3 & Jul-06 & 6 \\
Nov-03 & 1 & Dec-06 & 2 \\
Jan-04 & 1 & Jan-07 & 2 \\
Feb-04 & 1 & Oct-07 & 1 \\
Apr-04 & 4 & Dec-07 & 2 \\
Jun-04 & 2 & Apr-08 & 6 \\
Sep-04 & 3 & Aug-08 & 1 \\
Oct-04 & 4 & Grand & 120 \\
\hline Sour QKL & 1 & \\
\hline
\end{tabular}

Source: QKL (National License Registration Center)

Table A1: List of TV and Radio licenses issued in Albania by month and year 